\title{
SINTESIS DAN UJI TOKSISITAS SENYAWA ANALOG KALKON TURUNAN 2'-HIDROKSIASETOFENON DAN HALOBENZALDEHID
}

\author{
Ihsan Ikhtiarudin, Lelani, Adel Zamri, Hilwan Yuda Teruna, Yuharmen
}

Grup Riset Sintesis Organik, Jurusan Kimia, FMIPA, Unversitas Riau

Email: ihsan_ikhtiarudin@yahoo.com

\begin{abstract}
ABSTRAK
Kalkon merupakan senyawa metabolit sekunder golongan flavonoid yang terdapat pada beberapa jenis tumbuhan. Senyawa ini dikenal memiliki berbagai bioaktivitas yang menarik. Dalam bidang sintesis, senyawa ini digunakan untuk mensintesis berbagai macam senyawa heterosiklik seperti benzodiazepin, pirazolin, flavanon, flavonol, dan senyawa turunan kalkon lainnya yang juga memiliki bioaktivitas yang menarik. Oleh karena itu, senyawa ini banyak dijadikan sebagai molekul target untuk keperluan pencarian senyawa-senyawa aktif sebagai kandidat obat, salah satunya adalah sebagai obat antikanker. Pada penelitian ini, tiga analog kalkon turunan 2'-hidroksiasetofenon dan halobenzaldehid telah disintesis menggunakan metode stirer dengan katalis KOH dan pelarut PEG-400. Struktur setiap produk dikarakterisasi dengan spektroskopi UV-Vis, FTIR, ${ }^{1} \mathrm{H}$ NMR, ${ }^{13} \mathrm{C}$ NMR, dan HRMS. Uji toksisitas dilakukan menggunakan metode Brine Shrimp Lethality Test (BSLT). Berdasarkan hasil uji BSLT, ketiga senyawa tersebut berpotensi sebagai senyawa antikanker dengan nilai $\mathrm{LC}_{50}<200 \mu \mathrm{g} / \mathrm{mL}$.
\end{abstract}

Kata Kunci: kalkon, uji toksisitas, Brine Shrimp Lethality Test (BSLT)

\section{PENDAHULUAN}

Kanker merupakan penyakit yang ditandai dengan pertumbuhan yang tidak terkontrol dari sel-sel abnormal dan menjadi masalah utama di seluruh dunia. Penyakit ini adalah penyakit fatal dan diprediksikan sebagai salah satu penyakit penyebab utama kematian di masa depan. Meskipun penelitian tentang kanker telah menghasilkan sejumlah solusi baru, obat-obatan yang digunakan dalam pengobatan kanker masih memiliki banyak keterbatasan. Oleh karena itu, hingga saat ini penelitian yang berhubungan dengan penemuan obat antikanker baru yang ampuh, aman dan selektif masih terus dilakukan oleh para peneliti.

Kalkon merupakan senyawa metabolit sekunder golongan flavonoid yang dapat ditemukan pada beberapa jenis tumbuhan. Senyawa kalkon dan turunannya dikenal memiliki beragam aktivitas biologi yang menarik, seperti antimikroba (Tiwari et al.,
2010), antimalaria, antioksidan, antitumor (Prasad et al., 2006), anti-inflamasi (Yadav et al., 2011), antikanker (Syam et al., 2012) dan lain sebagainya. Dalam bidang sintesis, senyawa kalkon telah banyak digunakan untuk membuat berbagai macam senyawa heterosiklik (Tiwari $e t$ al., 2010) seperti isoksazol, quinolinon, tiadiazin, benzodiazepin, flavon (Jayapal et al., 2010b), ketimin $\alpha, \beta$ tak jenuh (Lonkar et al., 2011), pirazolin dan turunannya (Sharshira \& Hamada, 2011; Sing et al., 2009), flavonol (Britton et al., 2012; Jadhav et al., 2008), flavanonol (Patil, 2012) flavanon (Kulkarni, 2012) dan senyawa turunan lainnya (Gambar 9) yang juga memiliki aktivitas biologi yang menarik. Oleh karena itu, senyawa-senyawa analog kalkon dan turunannya banyak dijadikan sebagai molekul target untuk keperluan pencarian senyawa-senyawa aktif sebagai kandidat obat, salah satunya adalah sebagai obat antikanker. 


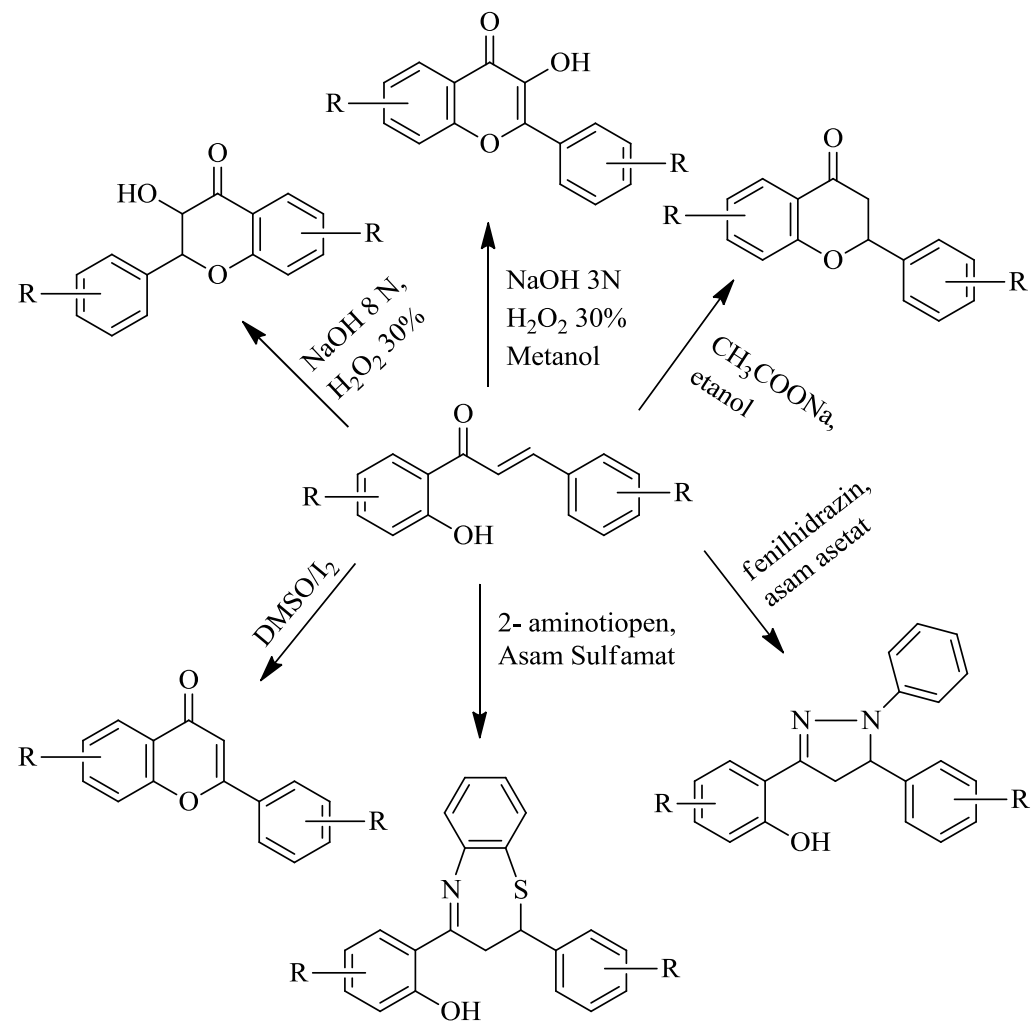

Gambar 4. Berbagai senyawa turunan 2'-hidroksikalkon

Aktivitas biologis kalkon, selain disebabkan oleh gugus karbonil $\alpha, \beta$ tak jenuh, juga dipengaruhi oleh subtituen yang terikat pada kedua cincin aromatik (Kamble et al., 2011). Oleh karena itu, variasi subtituen pada cincin aromatik akan menghasilkan kalkon dengan struktur yang beragam. Kalkon dengan variasi struktur yang luas hanya dapat diperoleh melalui sintesis secara kombinatorial. Untuk maksud tersebut, penulis telah mencanangkan program sintesis 100 molekul kalkon untuk dipelajari sifat fisiko-kimia dan bioaktivitasnya. Pada penelitian ini hanya dillaporkan sintesis tiga analog kalkon menggunakan senyawa awal 2'hidroksiasetofenon dan halobenzaldehid.

Salah satu metode baru untuk sintesis analog 2'-hidroksikalkon adalah dengan penggunaan PEG-400 (polietilenglikol-400) sebagai pelarut alternatif. Penggunaan PEG-400 ini bertujuan untuk mengurangi penggunaan pelarut organik volatil (Jayapal et al., 2010b), sehingga dapat dikatakan lebih ramah lingkungan. Sintesis dilakukan melalui reaksi kondensasi ClaisenSchmidt menggunakan bahan baku yang tersedia di pasaran. Reaksi ini juga telah dikenal sebagai reaksi yang ramah lingkungan. Sintesis menggunakan pendekatan metode ramah lingkungan yang dibantu dengan penggunaan pelarut non volatil ini dilakukan untuk meningkatkan efisiensi dalam produksi dan mengurangi dampak negatif terhadap lingkungan.

Ada dua masalah utama dalam mensintesis analog 2'-hidroksikalkon. Pertama, rendemen yang dihasilkan sedikit. Hal ini dikarenakan terjadinya reaksi pembentukan produk samping berupa senyawa flavanon akibat siklisasi produk 2'-hidroksikalkon (Patil et al., 2009; Stoyanov et al., 2002). Kedua, adanya substituen hidroksi pada cincin aromatik reaktan dapat menurunkan efektifitas dari katalis basa yang digunakan (Patil et al., 2009). Selain menyerang hidrogen $\alpha$ yang bersifat asam, katalis basa juga dapat menyerang hidrogen fenolik pada reaktan yang juga bersifat asam, sehingga dapat menghambat proses pembentukan ion enolat. Oleh karena itu, untuk mensintesis analog kalkon dengan substituen hidroksi diperlukan konsentrasi katalis basa yang lebih tinggi dibandingkan dengan konsentrasi reaktannya. 
Senyawa hasil sintesis dikarakterisasi berdasarkan interpretasi data spektroskopi UVVis, FTIR, ${ }^{1} \mathrm{H}$ NMR, ${ }^{13} \mathrm{C}$ NMR, dan HRMS kemudian diuji sifat toksiknya dengan metode Brine Shrimp Lethality Test (BSLT). Uji BSLT merupakan salah satu teknik pendahuluan untuk menentukan letalitas atau toksisitas suatu senyawa. Uji ini merupakan uji pendahuluan untuk menentukan aktivitas antikanker dari suatu senyawa. Hal ini didasarkan pada pemikiran bahwa sebagian besar senyawa antikanker adalah bersifat toksik. Pengujian letalitas sederhana ini tidak spesifik untuk antikanker, tetapi merupakan indikator sitotoksik yang baik (Meyer et al., 1982). Berdasarkan metode BSLT, suatu tanaman atau hasil isolasi dianggap menunjukkan aktivitas sitotoksik bila mempunyai nilai LC $_{50}$ kecil dari 1000 ppm, sedangkan untuk senyawa murni dianggap menunjukkan aktivitas sitotoksik bila mempunyai nilai LC $_{50}$ kecil dari 200 ppm (Anderson et al., 1991)

\section{METODOLOGI PENELITIAN Bahan dan Peralatan}

Bahan-bahan yang digunakan dalam penelitian ini adalah 2'-hidroksi asetofenon (Merck), 2-klorobenzaldehid (Merck), 3bromobenzaldehid (Merck), 4-klorobenzaldehid (Merck), polietilenglikol-400 (Merck), dimetilsulfoksida (Merck), kalium hidroksida (Merck), asam klorida $1 \mathrm{~N}$, telur udang (Artemia salina Leach), air laut dan pelarut-pelarut organik yang umum digunakan.

Alat-alat yang digunakan dalam penelitian ini adalah alat pengukur titik leleh (Fisher John), HPLC (Shimadzu LCsolution, jenis kolom ShimPack VP-ODS dengan panjang dan diameternya $150 \mathrm{x} 4,6 \mathrm{~mm}$ ), spektrofotometer UV-Vis (Genesys 10S UV-VIS v4.002 2L9N175013), spektrofotometer FTIR (Shimadzu, IR Prestige21), spektroskopi ${ }^{1} \mathrm{H}$ NMR dan ${ }^{13} \mathrm{C}$ NMR (Agilent $500 \mathrm{MHz}$ ) di Institut Teknologi Bandung, spektroskopi massa (MS water LCT premier XE positive mode) di Institut Teknologi Bandung, alat-alat untuk sintesis dan uji toksisitas yang umum digunakan di laboratorium.

\section{Prosedur Kerja Sintesis}

2'-hidroksiasetofenon (5 mmol) dan masingmasing halobenzaldehid $(5 \mathrm{mmol})$ dilarutkan dengan dalam 5 mL PEG-400 di dalam labu bulat yang telah dilengkapi magnet stirrer, kemudian distirer selama 2 menit. Setelah itu, sebanyak 15 mmol $\mathrm{KOH}$ padat ditambahkan ke dalam labu yang berisi campuran reaktan tersebut, kemudian distirer selama 8-12 jam. Tahapan reaksi dipantau melalui uji KLT. Setelah reaksi selesai, ke dalam campuran reaksi ditambahkan $\mathrm{HCl} 1 \mathrm{~N}$ dingin sebanyak $10 \mathrm{~mL}$ atau hingga $\mathrm{pH}$ netral dan terbentuk endapan. Endapan disaring dengan corong bunchner, kemudian dicuci dengan akuades dan n-heksan dingin. Selanjutnya Crude product diuji KLT, jika terdapat lebih dari satu noda, maka dilakukan rekristalisasi dengan EtOAc panas dan $n$-heksan untuk mendapatkan senyawa murni.

\section{Uji Toksisitas dengan Metode Brine Shrimp Lethality Test (BSLT)}

Uji toksisitas dengan metode BSLT dilakukan berdasarkan metode yang telah dilakukan oleh Meyer et al. (1982). Kista udang A. salina ditetaskan dalam wadah pembiakan yang berisi air laut, dan digunakan setelah aerasi selama 48 jam (setelah terbentuk larva). Vial uji dikalibrasi dengan $5 \mathrm{~mL}$ aquades. Pengujian dilakukan dengan konsentrasi 100, 10 dan 1 $\mu \mathrm{g} / \mathrm{mL}$ masing-masing dengan tiga kali pengulangan. Sampel sebanyak $20 \mathrm{mg}$ dilarutkan dalam $2 \mathrm{~mL}$ metanol (larutan induk, konsentrasi $10000 \mu \mathrm{g} / \mathrm{mL}$ ), kemudian dari larutan induk dibuat konsentrasi larutan uji $100 \mu \mathrm{g} / \mathrm{mL}, 10$ $\mu \mathrm{g} / \mathrm{mL}$, dan $1 \mu \mathrm{g} / \mathrm{mL}$ dengan cara pengenceran bertingkat. Sampel dipipet kedalam masingmasing vial sebanyak $0,5 \mathrm{~mL}$, lalu pelarut diuapkan hingga mengering. Selanjutnya, ditambahkan $50 \mu \mathrm{L}$ DMSO, 10 ekor larva Artemia salina Leach dan air laut sampai batas kalibrasi $5 \mathrm{~mL}$. Kematian larva dihitung dalam selang waktu 24 jam. Pengujian dilakukan sebanyak tiga kali pengulangan dengan perlakuan yang sama untuk masing-masing konsentrasi. Data yang diperoleh dianalisis untuk menentukan nilai $\mathrm{LC}_{50}$ dengan metode kurva menggunakan tabel analisis probit (Harefa, 1997). 


\section{HASIL DAN PEMBAHASAN}

Sintesis dilakukan menggunakan metode stirer dengan katalis $\mathrm{KOH}$ padat dan pelarut PEG-400 pada suhu ruangan. Skema reaksi sintesis senyawa kalkon tersebut dapat dilihat pada Gambar 10.

Rendemen yang dihasilkan cukup baik (56-80\%). Kemurnian senyawa kalkon hasil sintesis ditentukan melalui uji KLT, uji titik leleh, dan analisis HPLC. Uji KLT dilakukan menggunakan eluen n-heksana:etil asetat
(9:1) menunjukkan satu noda. Uji titik leleh menunjukkan kisaran titik leleh $\leq 2^{\circ} \mathrm{C}$. Analisis kemurnian dengan HPLC manghasilkan kromatogram dengan satu puncak dominan pada $t_{R}=16$ menit untuk senyawa (1), $t_{R}=17$ menit untuk senyawa (2), dan $t_{R}=16,20$ menit untuk senyawa (3). Sifat Fisik senyawa (1)-(3) dapat dilihat pada

\section{Tabel 1.}<smiles>CC(=O)c1ccccc1O</smiles>

$5 \mathrm{mmol}$<smiles>[R]c1ccc(C=O)c([R])c1[R]</smiles>

$5 \mathrm{mmol}$

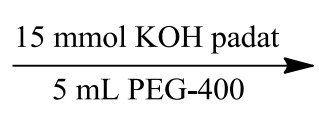<smiles>[R]c1ccc(/C=C/C(=O)c2ccccc2O)c([R])c1[R]</smiles>

(1) $\begin{aligned} & \mathrm{R}_{1}=\mathrm{Cl}, \\ & \mathrm{R}_{2}=\mathrm{H}, \mathrm{R}_{3}=\mathrm{H} \\ & \mathrm{R}_{1}=\mathrm{H},\end{aligned} \mathrm{R}_{2}=\mathrm{Br}, \quad \mathrm{R}_{3}=\mathrm{H}$

(3) $\quad \mathrm{R}_{1}=\mathrm{H}, \quad \mathrm{R}_{2}=\mathrm{H}, \mathrm{R}_{3}=\mathrm{Cl}$

Gambar 1. Reaksi sintesis senyawa kalkon turunan 2'-hidroksiasetofenon

Tabel 1. Sifat fisik senyawa analog kalkon (1)-(3)

\begin{tabular}{ccccccc}
\hline Senyawa & $\begin{array}{c}\text { Rumus } \\
\text { Molekul }\end{array}$ & $\begin{array}{c}\text { Berat } \\
\text { Molekul }\end{array}$ & $\begin{array}{c}\text { Rendemen } \\
(\%)\end{array}$ & Warna & $\begin{array}{c}\text { Titik leleh } \\
\left({ }^{\circ} \mathrm{C}\right)\end{array}$ & $\begin{array}{c}\mathrm{R}_{\mathrm{f}} \\
(\text { n-heksan:EtOAc) }\end{array}$ \\
\hline$(1)$ & $\mathrm{C}_{15} \mathrm{H}_{11} \mathrm{ClO}_{2}$ & 258,0515 & 56 & Kuning & $84-85$ & $0,51(9: 1)$ \\
$(2)$ & $\mathrm{C}_{15} \mathrm{H}_{11} \mathrm{BrO}_{2}$ & 302,0030 & 62 & Kuning & $82-83$ & $0,61(9: 1)$ \\
$(3)$ & $\mathrm{C}_{15} \mathrm{H}_{11} \mathrm{ClO}_{2}$ & 258,0537 & 80 & Orange & $80-81$ & $0,64(9: 1)$ \\
\hline
\end{tabular}

Spektrum UV senyawa (1)-(3) dalam pelarut methanol $(\mathrm{MeOH})$ sebagaimana dapat dilihat pada Gambar 2 berturut-turut memperlihatkan adanya serapan maksimum pada $\lambda 208 \mathrm{~nm}$ dan $309 \mathrm{~nm}$ dan puncak bahu pada $232 \mathrm{~nm}$ dan 366 nm untuk senyawa (1), serapan maksimum pada $\lambda 205 \mathrm{~nm}$ dan $319 \mathrm{~nm}$ dan puncak bahu pada 225 $\mathrm{nm}$ dan $364 \mathrm{~nm}$ untuk senyawa (2), serapan maksimum pada $\lambda 204 \mathrm{~nm}$ dan $319 \mathrm{~nm}$ dan puncak bahu pada $223 \mathrm{~nm}$ dan $365 \mathrm{~nm}$ untuk senyawa (3) menunjukkan adanya ikatan rangkap terkonjugasi yang merupakan ciri khas dari senyawa kalkon.

Spektrum FTIR senyawa (1)-(3) memperlihatkan adanya serapan pada bilangan gelombang $\left(\mathrm{cm}^{-1}\right)$ 1640-1644 mengindikasikan adanya gugus $\mathrm{C}=\mathrm{O}$ terkonjugasi dengan ikatan rangkap $\alpha, \beta$ tak jenuh. Serapan pada bilangan gelombang 1578-1583 mengindikasikan adanya ikatan $\mathrm{C}=\mathrm{C}$ alkena yang terkonjugasi dengan karbonil dan cincin aromatik. Serapan pada bilangan gelombang 3067-3086 mengindikasikan adanya ikatan $\mathrm{C}-\mathrm{H}$ aromatik. Serapan pada bilangan gelombang 2937-2958 mengindikasikan adanya ikatan $\mathrm{C}-\mathrm{H}$ alifatik. Serapan pada bilangan gelombang 1204-1206 mengindikasikan adanya ikatan $\mathrm{C}-\mathrm{O}$ alkohol. Vibrasi ikatan $\mathrm{C}-\mathrm{X}$ pada senyawa (1)-(3) masing-masing ditunjukkan pada bilangan gelombang $\left(\mathrm{cm}^{-1}\right) 751(\mathrm{C}-\mathrm{Cl}) 673(\mathrm{C}-\mathrm{Br})$, dan 761 (C-Cl). Serapan pada daerah bilangan gelombang tersebut sangat sesuai untuk mendeskripsikan gugus fungsi yang terdapat pada ketiga senyawa kalkon. 


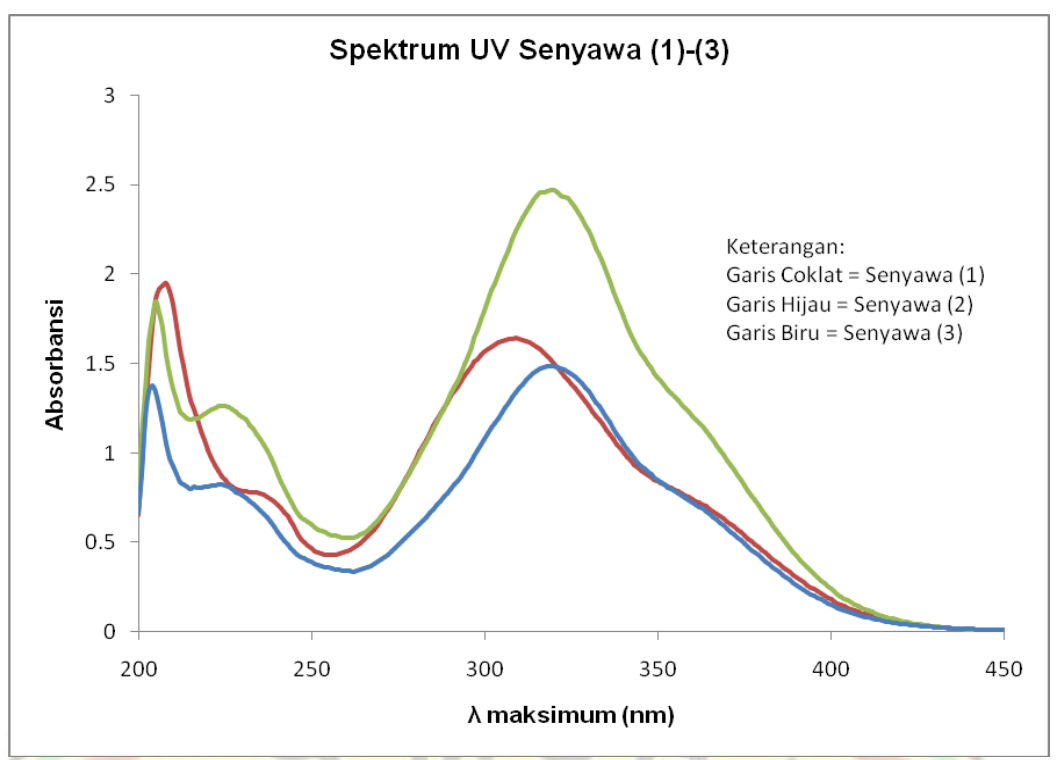

Gambar 2. Spektrum UV Senyawa (1)-(3) dalam pelarut $\mathrm{MeOH}$

Spektrum ${ }^{1} \mathrm{H} \quad \mathrm{NMR}$ senyawa (1) menunjukkan pergeseran kimia yang khas pada $\delta 7,82-\delta 8,32 \mathrm{ppm}(\mathrm{d}, 1 \mathrm{H}, J=15-15,5 \mathrm{~Hz})$ dan $\delta$ 7,62-7,66 ppm (d, $1 \mathrm{H}, J=15-15,5 \mathrm{~Hz})$ berturutturut menunjukkan adanya proton pada $\mathrm{C}_{\beta}$ dan $\mathrm{C}_{\alpha}$. Berdasarkan harga tetapan kopling $(J)$ dapat ditentukan bahwa senyawa kalkon tersebut memiliki konfigurasi trans $(E)$. Adanya proton pada $\delta$ 12,7-12,74 ppm menunjukkan bahwa pada ketiga senyawa kalkon terdapat proton dari substituen hidroksi (-OH) yang terikat pada cincin aromatik. Interpretasi spektrum ${ }^{1} \mathrm{H}$ NMR senyawa analog kalkon (1)-(3) dapat dilihat pada Tabel 2.

Tabel 2. Interpretasi data ${ }^{1} \mathrm{H}$ NMR senyawa analog kalkon (1), (2), dan (3)

\begin{tabular}{|c|c|c|c|}
\hline \multirow{2}{*}{$\begin{array}{c}\text { Nomor } \\
\text { Atom }\end{array}$} & \multirow{2}{*}{$\begin{array}{c}\text { Senyawa (1) } \\
\delta_{\mathrm{H}}(\mathrm{ppm}) \\
\end{array}$} & \multirow{2}{*}{$\frac{\text { Senyawa (2) }}{\delta_{\mathrm{H}}(\mathrm{ppm})}$} & \multirow{2}{*}{$\begin{array}{c}\text { Senyawa (3) } \\
\delta_{\mathrm{H}}(\mathrm{ppm})\end{array}$} \\
\hline & & & \\
\hline 1 & & - & - \\
\hline 2 & $-128=$ & $7,81(\mathrm{t}, 1 \mathrm{H}, \mathrm{J}=2 \mathrm{~Hz})$ & $7,59(\mathrm{~d}, 1 \mathrm{H}) \mathrm{J}=9 \mathrm{~Hz}$ \\
\hline 3 & $7,47(\mathrm{dd}, 1 \mathrm{H})$ & - & $7,41(\mathrm{~d}, 1 \mathrm{H}) \mathrm{J}=8,5 \mathrm{~Hz}$ \\
\hline 4 & $7,36(\mathrm{~m}, 1 \mathrm{H})$ & $7,55(\mathrm{td}, 1 \mathrm{H}) \mathrm{J}=8 ; 1,5 \mathrm{~Hz}$ & \\
\hline 5 & $7,36(\mathrm{~m}, 1 \mathrm{H})$ & $7,31(\mathrm{t}, 1 \mathrm{H}) \mathrm{J}=7,5 \mathrm{~Hz}$ & $7,41(\mathrm{~d}, 1 \mathrm{H}) \mathrm{J}=8,5 \mathrm{~Hz}$ \\
\hline 6 & $7,78(\mathrm{dd}, 1 \mathrm{H})$ & $7,55(\mathrm{td}, 1 \mathrm{H}) \mathrm{J}=8 ; 1,5 \mathrm{~Hz}$ & $7,59(\mathrm{~d}, 1 \mathrm{H}) \mathrm{J}=9 \mathrm{~Hz}$ \\
\hline $\mathrm{C} \alpha$ & $7,66(\mathrm{~d}, 1 \mathrm{H}, \mathrm{J}=15 \mathrm{~Hz})$ & $7,63(\mathrm{~d}, 1 \mathrm{H}, \mathrm{J}=15,5 \mathrm{~Hz})$ & $7,62(\mathrm{~d}, 1 \mathrm{H}, \mathrm{J}=15,5 \mathrm{~Hz})$ \\
\hline $\mathrm{C} \beta$ & $8,32(\mathrm{~d}, 1 \mathrm{H}, \mathrm{J}$ & $7,82(\mathrm{~d}, 1 \mathrm{H}, \mathrm{J}=15,5 \mathrm{~Hz})$ & $7,86(\mathrm{~d}, 1 \mathrm{H}, \mathrm{J}=15,5 \mathrm{~Hz})$ \\
\hline & $=15 \mathrm{~Hz})$ & & \\
\hline 1 ' & - & & \\
\hline 2 , & $12,73(\mathrm{~s}, 1 \mathrm{H},-\mathrm{OH})$ & $12,7(\mathrm{~s}, 1 \mathrm{H},-\mathrm{OH})$ & $12,74(\mathrm{~s}, 1 \mathrm{H},-\mathrm{OH})$ \\
\hline 3 ' & $7,05(\mathrm{dd}, 1 \mathrm{H})$ & $7,04(\mathrm{dd}, 1 \mathrm{H}) \mathrm{J}=8,5 ; 0,5 \mathrm{~Hz}$ & $7,03(\mathrm{~d}, 1 \mathrm{H}) \mathrm{J}=8,5 \mathrm{~Hz}$ \\
\hline 4 , & $7,52(\mathrm{t}, 1 \mathrm{H})$ & $7,51(\mathrm{t}, 1 \mathrm{H}) \mathrm{J}=7,5 \mathrm{~Hz}$ & $7,51(\mathrm{t}, 1 \mathrm{H}) \mathrm{J}=7,75 \mathrm{~Hz}$ \\
\hline 5 , & $6,96(\mathrm{t}, 1 \mathrm{H})$ & $6,96(\mathrm{t}, 1 \mathrm{H}) \mathrm{J}=8 \mathrm{~Hz}$ & $6,95(\mathrm{t}, 1 \mathrm{H}) \mathrm{J}=7,5 \mathrm{~Hz}$ \\
\hline 6 , & $7,92(\mathrm{dd}, 1 \mathrm{H})$ & $7,91(\mathrm{dd}, 1 \mathrm{H}) \mathrm{J}=8 ; 1,5 \mathrm{~Hz}$ & $7,90(\mathrm{dd}, 1 \mathrm{H}) \mathrm{J}=8 ; 1,5 \mathrm{~Hz}$ \\
\hline
\end{tabular}

Spektrum ${ }^{13} \mathrm{C}$ NMR senyawa (1)-(3) menunjukkan pergeseran kimia pada $\delta$ 193,3193,49 ppm yang menunjukkan adanya atom C karbonil pada ketiga senyawa kalkon. Pergeseran kimia karbon pada $\delta$ 163,6-163,62 ppm menunjukkan adanya substituen hidroksi $(\mathrm{OH})$ yang terikat pada cincin aromatik.
Interpretasi data spektrum ${ }^{1} \mathrm{H}$ NMR dan ${ }^{13} \mathrm{C}$ NMR senyawa (1) telah dikonfirmasi dengan spektrum HMQC dan HMBC yang secara keseluruhan menunjukkan korelasi ikatan yang sesuai untuk struktur senyawa tersebut sebagaimana ditunjukkan masing-masing pada Gambar 3. 


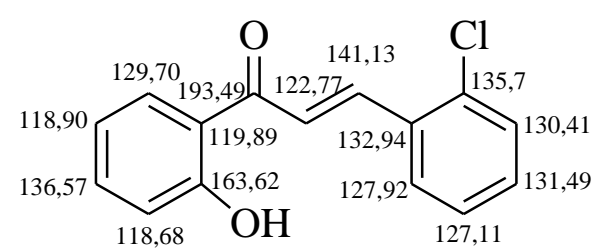

(a)

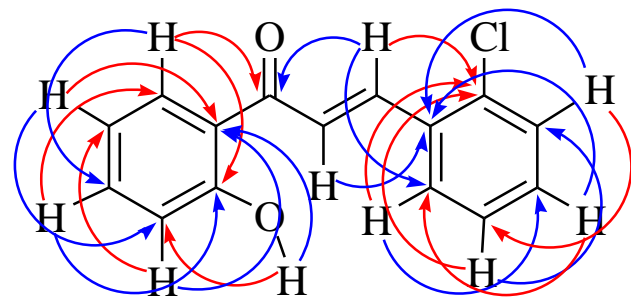

(b)

Gambar 3. Korelasi ikatan pada senyawa (1): Korelasi ikatan pada spektrum HMQC (a), dan HMBC

Berat molekul senyawa-senyawa hasil sintesis dikonfirmasi melalui spektroskopi massa (HRMS). Berat molekul senyawa (1) ditunjukkan oleh spektrum massa yang dihitung sebagai $\mathrm{C}_{15} \mathrm{H}_{12} \mathrm{O}_{2} \mathrm{Cl}[\mathrm{M}+\mathrm{H}]^{+}$dengan puncak ion molekul 259,0526 m/z dan ditemukan pada spektrum massa dengan puncak ion molekul $259,0515 \mathrm{~m} / \mathrm{z}$, selisih massa molekul tersebut 0,0011 . Berat molekul senyawa (2) ditunjukkan oleh spektrum massa yang dihitung sebagai $\mathrm{C}_{15} \mathrm{H}_{12} \mathrm{O}_{2} \mathrm{Br} \quad[\mathrm{M}+\mathrm{H}]^{+}$dengan puncak ion molekul 303,0021 m/z dan ditemukan pada spektrum massa dengan puncak ion molekul $303,0030 \mathrm{~m} / \mathrm{z}$, selisih massa molekul tersebut 0,0009 . Berat molekul senyawa (3) ditunjukkan oleh spektrum massa yang dihitung sebagai $\mathrm{C}_{15} \mathrm{H}_{12} \mathrm{O}_{2} \mathrm{Cl} \quad[\mathrm{M}+\mathrm{H}]^{+}$dengan puncak ion molekul 259,0526 m/z dan ditemukan pada spektrum massa dengan puncak ion molekul $259,0537 \mathrm{~m} / \mathrm{z}$, selisih massa 0,0011. Selisih massa berdasarkan spektrum massa dengan massa perhitungan menunjukkan perbedaan yang sangat kecil antara senyawa yang diharapkan dengan senyawa kalkon yang diperoleh dan dapat dikatakan bahwa senyawa kalkon tersebut sangat murni. Dengan demikian dapat dikatakan bahwa senyawa kalkon tersebut mempunyai struktur sesuai dengan yang diharapkan .

Uji toksisitas terhadap senyawa-senyawa kalkon turunan 2'-hidroksi asetofenon dilakukan menggunakan metode BSLT. Hasil uji toksisitas terhadap senyawa kalkon tersebut dapat dilihat pada Tabel 3 . (b).

Tabel 3. Hasil uji toksisitas

\begin{tabular}{ll}
\hline Senyawa & Nilai $\mathbf{L C}_{\mathbf{5 0}}(\boldsymbol{\mu} \mathbf{g} / \mathbf{m L})$ \\
\hline & \\
$(1)$ & 2,839 \\
$(2)$ & 1,495 \\
$(3)$ & 3,328
\end{tabular}

Berdasarkan uji BSLT yang telah dilakukan, dapat dikatakan bahwa senyawasenyawa kalkon turunan 2'-hidroksiasetofenon tersebut berpotensi aktif sebagai senyawa antikanker yang dibuktikan dengan nilai $\mathrm{LC}_{50}<200 \mu \mathrm{g} / \mathrm{mL}$.

\section{KESIMPULAN}

Melalui penelitian ini telah dihasilkan tiga analog kalkon turunan 2'hidroksi asetofenon dengan rendemen yang cukup baik (56-80 \%). Sintesis dilakukan melalui reaksi kondensasi Claisen-Schmidt menggunakan metode stirer dengan katalis $\mathrm{KOH}$ padat dan menggunakan PEG-400 sebagai pelarut yang bersifat non volatil dan lebih ramah lingkungan, sehingga dapat meminimalisir polusi. Hasil karakterisasi melalui spektroskopi UV-Vis, FTIR, ${ }^{1} \mathrm{H}$ NMR, ${ }^{13} \mathrm{C}$ NMR, dan HRMS menunjukkan bahwa ketiga senyawa hasil sintesis memiliki struktur sesuai dengan yang diharapkan. Berdasarkan hasil uji pendahuluan menggunakan metode BSLT dapat disimpulkan bahwa ketiga senyawa hasil sintesis berpotensi aktif sebagai senyawa antikanker yang dibuktikan dengan nilai $\mathrm{LC}_{50}<200 \mu \mathrm{g} / \mathrm{Mo}$.

\section{DAFTAR PUSTAKA}

Anderson, J.E. Goetz, C.M., dan Mclaughlin, J.L. 1991. A Blind Comparison of Simple Bench Top Bioassay and Human Tumor Cell Cytotoxicity as Antitumor Prescreens. Pytochemical Analysis. 2(3): 107-111. 
Britton, R.G., Horner-Glister, E., Pomenya, O.A., Smith, E.E., Denton, R., Jenkins, P.R., Steward, W.P., Brown, K., Gescher, A., dan Sale, S. 2012. Synthesis and Biological Evaluation of Novel Flavonols as Potential Anti-Prostate Cancer Agent. European Journal of Medicinal Chemistry. 54: 952-958.

Harefa, F. 1997. Pembudidayaan Artemia salina untuk Pakan Udang dan Ikan. Swadaya, Jakarta.

Jadhav, S.B., Bagul, K.R., Bagul, P.R., dan Gaikwad, K.V. 2008. Synthesis of Some Novel Flavonol Derivatives and Its Antimicrobial Activity. Oriental Journal of Chemistry. 24(2): 583-588.

Jayapal, M.R., Prasad, K.S., dan Sreedhar, N.Y. 2010. Synthesis and Characterization of 2,6-dihydroxy Substituted Chalcones Using PEG-400 as a Recyclable Solvent. J. Pharm. Sci \& Res. 2(8):450-458

Kamble, V.M., Hatnapure, G.D., Keche, A.P., Birajdar, S., Patil, S.G., Tale, R.H., Rodge, A.H., Turkar, S.S., dan Gour, K. 2011. Sintesis and Biological Evaluation of a Novel Series of Methoxylated Chalcones as Antioxidant and Anti-microbial agents. $J$. Chem. Pharm. Res. 3(6):639-648.

Kulkarni, P., Wagh, P., dan Zubaidha, P. 2012. An Improved and Eco-Friendly Method for The Synthesis of Flavanone by The Cyclization of 2'-Hydroxy Chalcone using Methane Sulphonic Acid as Catalyst. Chemistry Journal. 2(3): 106-110.

Lonkar, S.M., Mokle, S.S., Vibhute, A.Y., dan Vibhute, Y.B. 2011. Green Approach for The Synthesis of Some New $\alpha, \beta$ Unsaturated Ketimines under Water Suspension. Orbital Elec. J. Chem. 3(4):197-203.

Meyer, B.N., Ferrigni, N.R., Putnam, J.E., Jacosen, L.B., Nichols D.E., dan
McLaughin, J.L. 1982. Brine Shrimp: A Convenient General Bioassay for Active Plant Constituens. Journal of Medicinal Plant Research Planta Medica. 45: 31-34.

Patil, C.B., Mahajan, S.K., dan Katti, S.A. 2009. Chalcone: a Versatile Molecule. Journal of Pharmaceutical Science and Research. 1(3): 11-12.

Patil, V.J. 2012. Synthesis and In Vitro Antiplaque Activity of Chalcone, Flavonol and Flavanol Derivatives. IJPSR. 3(12): 5006-5014.

Prasad, Y.R., Kumar, P.R., Deepti, C.H.A., dan Ramana, M.V. 2006. Synthesis and antimicrobial activity of some novel chalcones of 2-hydroxy-1-acetonapthone and 3-acetyl coumarin. E-Journal of Chemistry. 3(4): 236-241.

Sharshira, E.M. dan Hamada, N.M.M. 2011. Synthesis and In Vitro Antimicrobial Activity of Some Pyrazolyl-1-carboxamide Derivatives. Molecules. 16: 7736-7745.

Sing, P., Negi, J.S., Pant, G.J.N., Rawat, M.S.M. \& Budakoti, A. 2009. Synthesis and Characterization of a Novel 2-Pyrazoline. Molbank, 613: 1-4.

Syam, S., Abdelwahab, S.I., Al-Mamary, M.A., dan Mohan, S. 2012. Synthesis of chalcones with anticancer activities. Molecules. 17: 6179-6195.

Tiwari, B., Pratapwar, A.S., Tapas, A.R., Butle, S.R., dan Vatkar, B.S. 2010. Synthesis and Antimicrobial Activity of some chalcone derivatives. International Journal of ChemTech Research. 2(1): 499-503.

Yadav, H.L., Gupta, P., Pawar, R.S., Singour, P.K., dan Patil, U.K. 2011. Synthesis and biological evaluation of anti-inflammatory activity of 1,3 diphenyl propenone derivatives. Medicinal Chemistry Research. 20: 461-465. 